\title{
Historical earthquakes and damage patterns in Potenza (Basilicata, Southern Italy)
}

\author{
Fabrizio Terenzio Gizzi and Nicola Masini \\ Istituto per i Beni Archeologici e Monumentali, CNR, Area della Ricerca di Potenza, Tito Scalo (PZ), Italy
}

\begin{abstract}
This paper analyzes three historical seismic damage patterns in Potenza, the main town of the Basilicata Region, in Southern Italy. We refer to the 1826, 1857 and 1930 earthquakes, which hit the town with intensities ranging from VI-VII to VIII-IX MCS. In order to depict the seismic effects, we analyzed original documents, most of them never consulted before. The events have been located on an urban map of Potenza dating back to 1875 . This research represents the starting point for further investigations, with the goal of highlighting the causes of the 'anomalies' in the distribution of the effects.
\end{abstract}

Key words Basilicata-Potenza-historical earthquake - damage pattern - seismic microzonation

\section{Introduction}

The use of historical data to analyze the effects of past earthquakes can meaningfully increase the knowledge about the seismic behaviour of the building-soil system. This approach can highlight urban areas where anomalously large damage occurred in the past. Further investigations may be able to determine the causes of the differential effects, which are usually due to geological/anthropic features of the territory and/ or building vulnerability (e.g., Guidoboni et al., 2003; Gizzi, 2006). In this way, potentially 'weak' urban zones can be identified so that suitable prevention strategies can be implemented.

To this purpose, we analyzed macroseismic data related to three historical earthquakes in

Mailing address: Dr. Fabrizio Terenzio Gizzi, Istituto per i Beni Archeologici e Monumentali, CNR, Area della Ricerca di Potenza, C.da S. Loja, 85050 Tito Scalo (PZ), Italy; e-mail: f.gizzi@ibam.cnr.it
Potenza, the main town of the Basilicata Region, in Southern Italy. Our findings constitute the starting point for further analyses aimed at highlighting the causes of 'anomalies' in damage distribution. In detail our research will make it possible to determine the areas subjected to heavier damage during historical events, which could be at risk in the event of future earthquakes. Further research based on data collection and analysis (e.g., field surveys, boreholes and geophysical prospecting) may be able to determine the impact of geological, geomorphological, geotechnical and hydrogeological features of the site on damage distribution. In this way, important implications will be gathered for the seismic microzonation of Po-tenza, based not only on the traditional approach but also on damage already experienced.

We studied the most damaging historical earthquakes (in 1826, 1857 and 1930) for which it has been possible to map the affected buildings. These events struck the town with intensities ranging from VI-VII to VIII-IX MCS (Boschi et al., 2000). We analyzed documents preserved in Potenza and in the Naples State Archive as well as in the Potenza Municipal Archive and in the Potenza Monuments and Fine Arts Office 
Archive. These data, in conjunction with urban, technical and cadastral information, enabled us to describe the three urban damage patterns.

\section{Outline of the seismic history of Potenza}

Potenza, a town with a population of about 70000 (Istat, 2005), is located on a hill in the

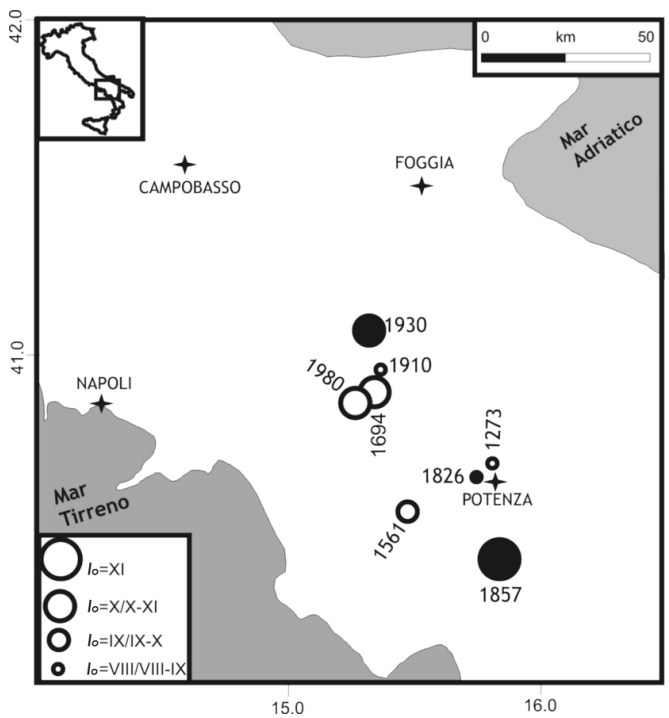

Fig. 1. Strongest historical earthquakes that affected Potenza. The circle diameter is proportional to the epicentral intensity (MCS). The black circles show the seismic events analysed in this paper. Data are drawn from Boschi et al. (2000).
Southern Apennines where an axial-active, 30 to $50 \mathrm{~km}$ wide seismic belt produces strong earthquakes (Boschi et al., 1999). Large past earthquakes originated in both inner areas of Basilicata and in areas located at the western and north-western boundaries, between Basilicata and Campania (fig. 1).

In historical times, Potenza was affected by at least five earthquakes with intensities higher than or equal to VIII MCS (table I).

The first documented event dates to 1273 (Io=VIII-IX MCS, $M e=5.7$ ). The only available written account states that in Potenza a large number of buildings suffered heavy damage. According to these data, the local effects were VIII MCS (Boschi et al., 2000).

About three centuries later, another seismic event occurred along the western boundary between Campania and Basilicata. The two main shocks (on July and August 1561) caused considerable damage, mainly in Potenza and Salerno. The first events (Io=IX-X MCS, $M e=6.5$ ) caused the collapse of 10 houses in Potenza, with no casualties (Boschi et al., 2000).

About a century later, the 1694 Irpinia-Basilicata earthquake ( $I o=\mathrm{X}$ MCS, $M e=6.8)$ caused the total destruction of 14 towns and great damage in 18 towns and villages along the Apennines. Pacichelli (1695) stated that: «In Potenza several buildings, the Church and the Trinità Tower collapsed. Five people died ...» («Cadde in Potenza con più fabbriche, la chiesa e la Torre della SS. Trinità, con la morte di cinque cittadini ...»).

The 1826 earthquake (Io=VIII MCS, Me= $=5.9$ ) originated in an area about $15 \mathrm{~km}$ from the

Table I. Strongest earthquakes felt in Potenza. In bold the earthquakes analysed in this paper. Events are extracted from Boschi et al. (2000). Io=epicentral intensity (MCS); Is=intensity in Potenza (MCS).

\begin{tabular}{ccccccccc}
\hline \hline Year & Month & Day & Lat & Long & Io & $I s$ & Epicentral area & Distance $(\mathrm{km})$ \\
\hline 1273 & - & - & 40.6 & 15.8 & VIII-IX & VIII-IX & Potenza & 1.0 \\
1561 & 8 & 19 & 40.5 & 15.5 & IX-X & VIII & Vallo di Diano & 17.6 \\
1694 & 9 & 8 & 40.9 & 15.4 & X & VIII & Irpinia-Basilicata & 31.0 \\
$\mathbf{1 8 2 6}$ & $\mathbf{2}$ & $\mathbf{1}$ & $\mathbf{4 0 . 5}$ & $\mathbf{1 5 . 7}$ & VIII & VIII & Basilicata & $\mathbf{1 7 . 0}$ \\
$\mathbf{1 8 5 7}$ & $\mathbf{1 2}$ & $\mathbf{1 6}$ & $\mathbf{4 0 . 4}$ & $\mathbf{1 5 . 9}$ & XI & VIII-IX & Basilicata & $\mathbf{4 0 . 0}$ \\
1910 & 06 & 07 & 40.9 & 15.4 & VIII & VI & Irpinia-Basilicata & 35.6 \\
$\mathbf{1 9 3 0}$ & $\mathbf{7}$ & $\mathbf{2 3}$ & $\mathbf{4 1 . 1}$ & $\mathbf{1 5 . 4}$ & $\mathbf{X}$ & VI-VII & Irpinia & $\mathbf{5 6 . 3}$ \\
1980 & 11 & 23 & 40.9 & 15.3 & X & VII & Irpinia-Basilicata & 28.3 \\
\hline
\end{tabular}




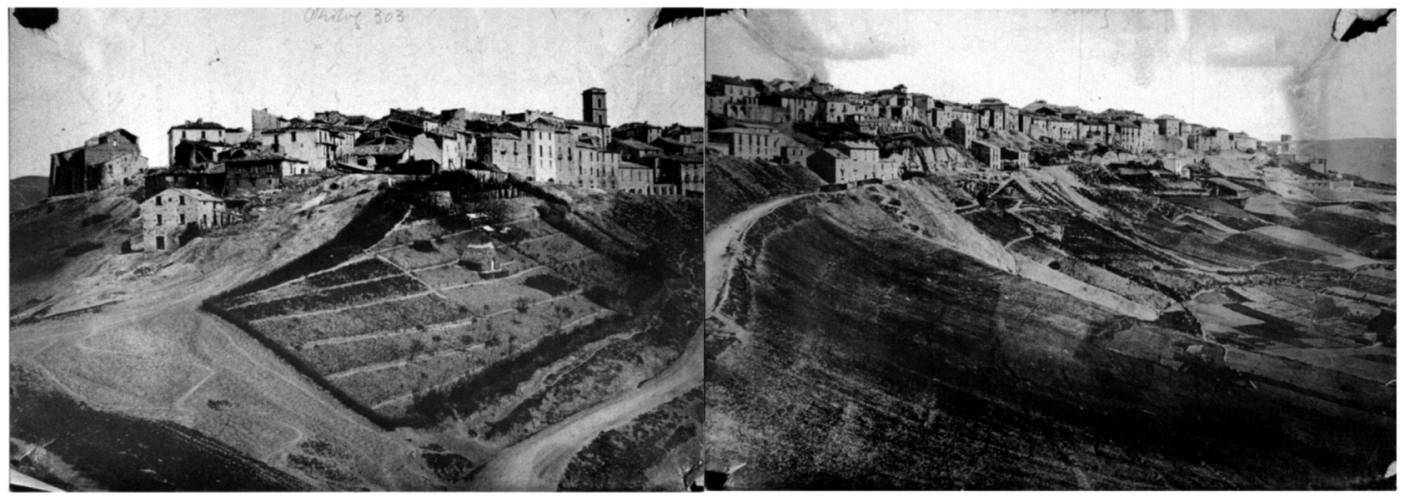

Fig. 2. General view of Potenza after the 1857 seismic event according to the Mallet's report (Mallet, 1862) (from the monoscopic photos no. 302 and 303).

main town and hit parts of the village of Tito, where about three fourths of the buildings collapsed and two quarters were completely destroyed (ASNa, Relazione del sottoingegnere ..., 1826).

A contemporary eyewitness related that in Potenza: « ... on 1 February 1826 at 5:15 p.m. a strong shake hit the chief-town. The Earth was shaken twice in the time-interval of one hour and again at 06:00 a.m. on 3 February ...» («... La sera del primo andante, circa le ore 5 e 15 pomeridiane fummo in questo capoluogo sorpresi da una forte scossa di tremuoto, che replicò per ben due volte nello spazio di un'ora e nuovamente la mattina del 3, circa le ore 6 antimeridiane ...») (ASNa, Relazione del sottoingegnere ..., 1826). As regards the effects in Potenza, Lombardi (1829) reported that: «... only two or three houses collapsed, but heavy damage was suffered by all private or public buildings ...» («... caddero soltanto due o tre vecchi abituri, ma ne rimasero grandemente danneggiati tutti gli edifici pubblici e, privati ...») and «... wall cracks appeared in almost all the buildings ...» («... quasi tutte le abitazioni dei privati provarono similmente gli effetti del tremuoto, e ne rimasero generalmente lesionate ...»).

The 1857 event (Io=XI MCS, Me=7.0) caused massive damage in about thirty towns of Basilicata and Campania. About 180 localities collapsed into ruins and 30 villages suffered meaningful damage. On the whole, the earth- quake hit about $20000 \mathrm{~km}^{2}$. As regards Potenza, Tomacelli (1892) stated that «...the entire town suffered damage; roofs collapsed, walls cracked and falling ... churches and mansions partially collapsed ...» («... Potenza sfracellò sotto il proprio peso quasi tutta; tetti sfondati, muraglia rotte e cadenti ... chiese e palagi parte sprofondati ...»).

The seismological importance of this earthquake led the Irish engineer Robert Mallet to visit the affected towns, including Potenza. For this locality, the scientist noticed that «...The damage done was very diffused over every part of the town, though greatest upon the free lying flanks, to the east, west, and N.W., and many buildings are prostrated or fractured ...» (Mallet, 1862) (fig. 2).

The last historical earthquake that affected the town happened on 23 July 1930. The Irpinia quake had an epicentral intensity and magnitude of $I o=\mathrm{X}$ MCS and $M e=6.7$ respectively, and hit at 00:08 GMT an area of about 6500 $\mathrm{km}^{2}$, killing 1404 people (Boschi et al., 2000). In several towns at the border between Campania and Basilicata, everything turned to dust and rubbish. The most affected area was the territory ranging from Melfi to Ariano Irpino. In Potenza, the damage was serious: 80 buildings were damaged (Alfano, 1931).

About thirty years ago, the Italy's largest natural catastrophe since World War II occurred. We refer to the 1980 Irpinia event $(I o=X \mathrm{MCS}, M e=$ 
=6.7). This earthquake devastated a wide area of the Southern Apennines, especially Campania and Basilicata where about thirty towns were completely destroyed. In Potenza 10000 people became homeless and public buildings suffered heavy damage (Il Mattino, 08/12/1980; Il Nuovo Corso 10/02/1981; Gazzetta del Mezzogiorno 30/12/1980).

Ten years later, on May 5, 1990, the Potenza seismic sequence occurred along an E-W striking vertical plane (Demanet et al., 1998). The local shaking felt was VI MCS, and the maximum intensity was recorded in Pietragalla (VII MCS), about $15 \mathrm{~km}$ from Potenza (Tertulliani et al., 1992).

\section{Seismic damage patterns: methodology and results}

As stated previously, this analysis focuses on the urban damage patterns from the earthquakes of 1826, 1857 and 1930. Published written accounts were not sufficient to locate urban effects, mainly for two reasons. First, there is little detailed information about damage; the second reason is the lack of 'toponymy markers' suitable to locate damage episodes on a map.

To overcome this lack of information, we analyzed unpublished written sources from the Potenza and Naples State Archives, as well as the Potenza Municipal Archive and the Potenza Monuments and Fine Arts Office Archive.

Bibliographic research also was undertaken to gain information about the historic, urban and social background of the town. Understanding these aspects allowed us to better interpret the damage as quoted in the written sources. All damage episodes were located on an urban map from 1875, approximately halfway in time between the first and last earthquakes.

The seismic effects have been classified according to the EMS-98 scale (Grünthal, 1998), which considers the following five damage classes for masonry buildings: slight, moderate, substantial to heavy, very heavy and destruction.

In order to correctly extract information from the historical accounts, we had to reconstruct administrative actions taken after each earthquake; a brief summary follows.
After the 1826 seismic event, a central commission was established with the task of supervising the rebuilding of damaged houses by distributing money to the owners of those houses. In Potenza, a local commission surveyed the damaged buildings as well, to decide whether or not to demolish severely damaged houses. These commissions were composed of administrators, technicians and representatives of the town clergy.

In order to detect damage, we first analyzed the resolutions of the local commission and correspondence between the municipal commission and the Intendenza (prefecture). We also studied about 20 letters mailed by house owners to the central commission so as to obtain subsidies to repair or rebuild the dwellings. Much of this correspondence contains descriptions of seismic effects; however, the owners tended to overestimate damage. Letters that cite unambiguous damage have been considered reliable (e.g., collapse of a wall, serious damage linked to demolition imposed by the municipal commission, etc.). The owners' damage descriptions were correlated with data drawn from the documents of the commissions. Therefore, by critically analyzing these written sources, we obtained more information about damage in urban areas. Several sources analysed are documents unpublished elsewhere (see Appendix).

In order to locate damaged buildings on the urban map, we had to address other problems. The locations (road, square, etc.) of houses are commonly not cited in historical records, nor are they referred to in old toponymy. To overcome these difficulties, we conducted a crosscorrelated analysis of cadastral data, old and current toponymy and site surveys. The descriptive French cadastre (so-called Catasto provvisorio) that dates back to the first decades of the nineteenth century was consulted. This guaranteed a nearly one-to-one correspondence with locations of buildings at the time of the earthquake.

Once the correct location was identified, the affected houses were located on the urban map, which dates to the second half of the nineteenth century. To obtain a better match with the urban setting at the time of the earthquake, urban features gathered from bibliographic analysis were 
integrated with the urban map (e.g., Buccaro, 1997).

The analysis of this earthquake highlights effects on the western flank of the hill and in the central-western part of the historical centre (fig. 3).

However, available written sources cannot completely depict the event. An engineer entrusted to verify the effects in Potenza wrote that: «... mostly damaged buildings are the Cathedral, the Church of San Gerardo and its bell-tower, the Church of Santa Trinità, the Palace of Intendenza ... and several dwellings of rich and poor owners whose list is long ...» ( «Gli edifici che più han sofferto sono l'Episcopio, la Chiesa ed il Campanile di S. Gerardo, la torre di San Carlo, la chiesa della SS. Trinità, il convento dei Riformati sotto il titolo di S. Maria, il Palazzo d'Intendenza e molte abitazioni di ricchi e poveri, di cui sarebbe lungo tesserne l'elenco ...») (ASNa, Relazione dell'Ingegnere provinciale Marino Massari al Signor Intendente ..., 1826).
Even though this research cannot indicate the causes of differential effects, it seems appropriate to emphasize the vulnerability of the buildings. The commission entrusted with surveying the damaged houses stressed that dwellings suffering damage were old, with preexisting cracks (Sannino, 1990). Moreover, after the earthquake, no work was undertaken toward systematically strengthening the buildings, due in part to the house owners' poverty. Thus, the stronger 1857 earthquake happened at a time of structural vulnerability.

Following the 1857 earthquake, central and local commissions were adopted as well. The damage pattern is here mainly 'reconstructed' on the basis of unpublished documents (see Appendix).

The resolutions of the commissions regarding the demolition of severely damaged houses and the distribution of subsidies to rebuild or to repair the houses are all unpublished. Also unpublished is the correspondence between house owners and the central commission intended to obtain subsi-

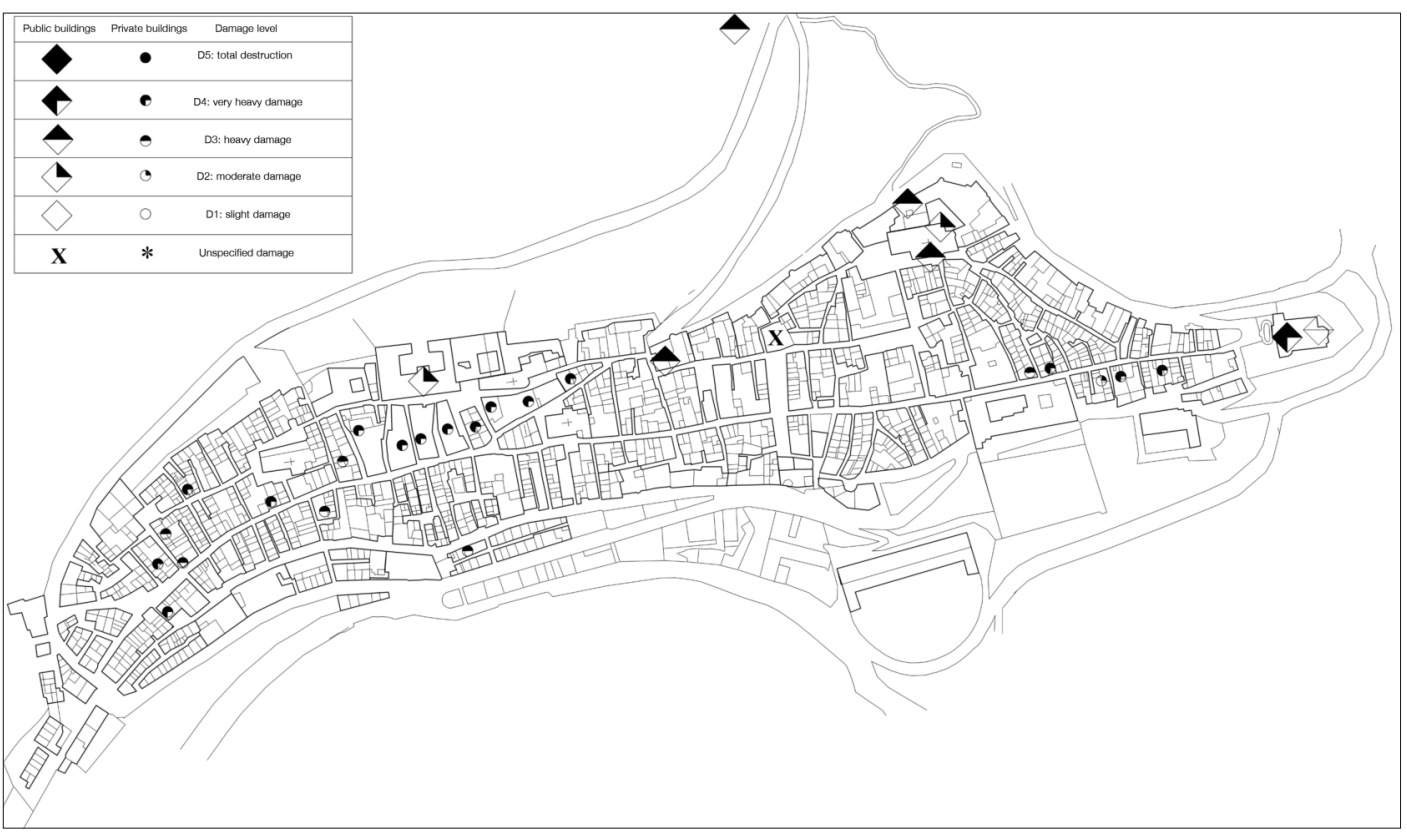

Fig. 3. 1826 damage 'scenario' for Potenza. The map highlights effects on the western flank of the hill and in the central-western area of the historical centre. 


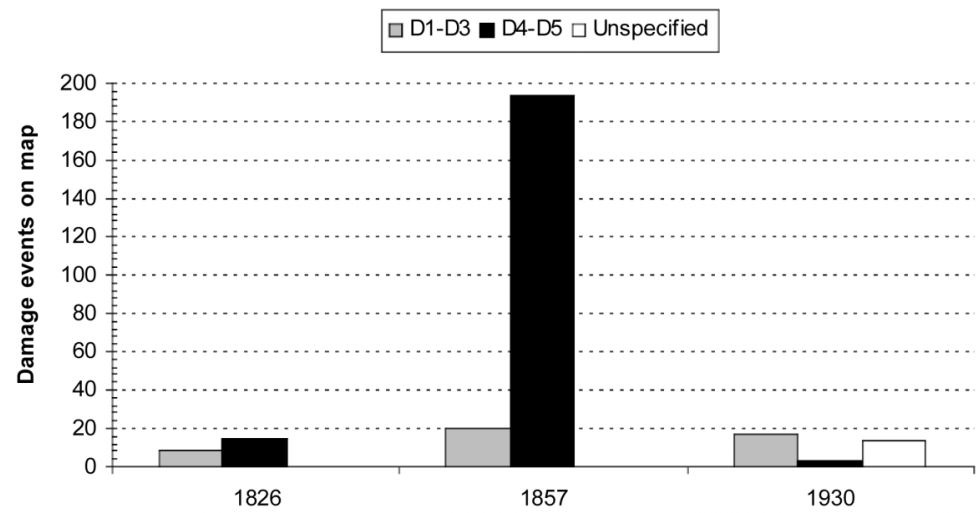

Fig. 4. Number of damage events pinpointed on the urban maps. Events are plotted as two different group of EMS damage classes (D1-D3 and D4-D5). The predominance of the higher classes of damage is due to the economic-administrative filter (see text).

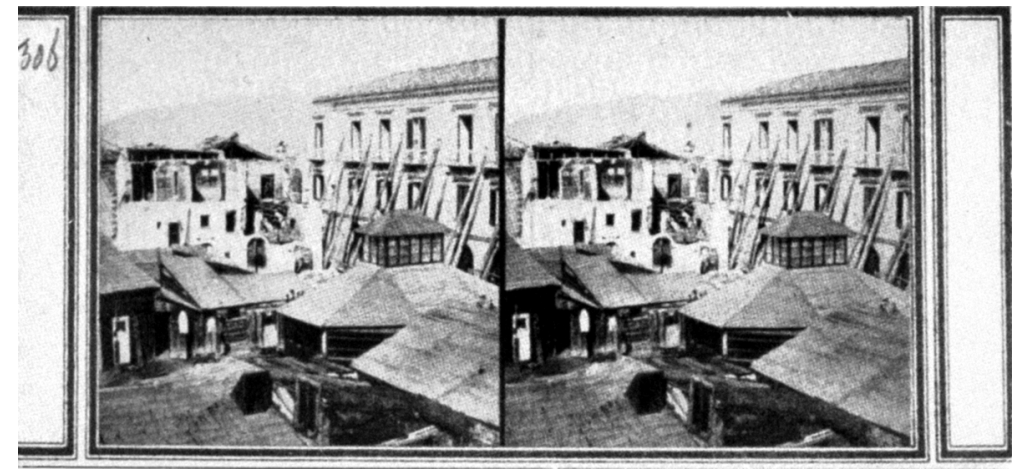

Fig. 5. Damage to the Palace of Intendenza (on the top in the right corner) according to the Mallet's report (Mallet, 1862, stereoscopic photo no. 306). Huts are also evident in the foreground.

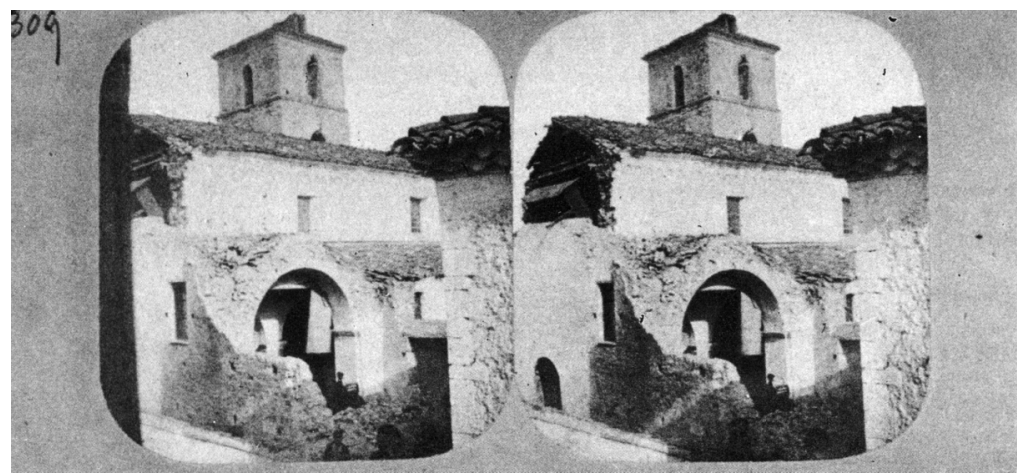

Fig. 6. Damage to the Church of St. Angelo della Trinità according to the Mallet's report (Mallet, 1862, stereoscopic photo no. 309). 
dies. The subsidies were assigned if a twofold condition was met: significant damage to the buildings and poor house owners. Obviously, this criterion filters damage evaluation and must be considered in the analysis of the effects (fig. 4).

We also analyzed the records of the Consiglio Edilizio (Angelini, 1995), a technical body established for 'urban planning'; this was very important in mapping the seismic effects. This source provided data about affected houses not included in other analyzed documentation, owing to the previously cited economicadministrative filter.

More data were gathered by cross-correlation of these last-mentioned dossiers and the documentation produced by the local and/or central commissions. In this way, information was obtained on both the damage and the locations of buildings. For locating dwellings, we discovered additional information from other kinds of sources coeval to the earthquake (e.g., list of house owners who made use of public works or list of dwellings demolished in order to construct new public buildings (ASCPz, Elenco complateari ..., 1857; ASCPz, Elenco delle case demolite ..., 1857). The French cadastre was not useful for locating damaged buildings because it was not coeval with any earthquake.

Damage to public or religious buildings was considered in both the archive sources and the surveys or photos attached to the Mallet report (Mallet, 1862) (figs. 5, 6). These photos helped locate some collapsed or affected buildings on the urban map.

At least ten aftershocks were felt in Potenza, lasting until November 1858 (Rossi, 1868). Therefore, it is clear that the classified damage could include cumulative effects of the earthquakes.

Using all the sources mentioned above, the localised damage events were pinpointed on the 1875 urban map. Figures 7 and 8 indicate that the effects were mainly localized in the western and central-western sectors of the historical

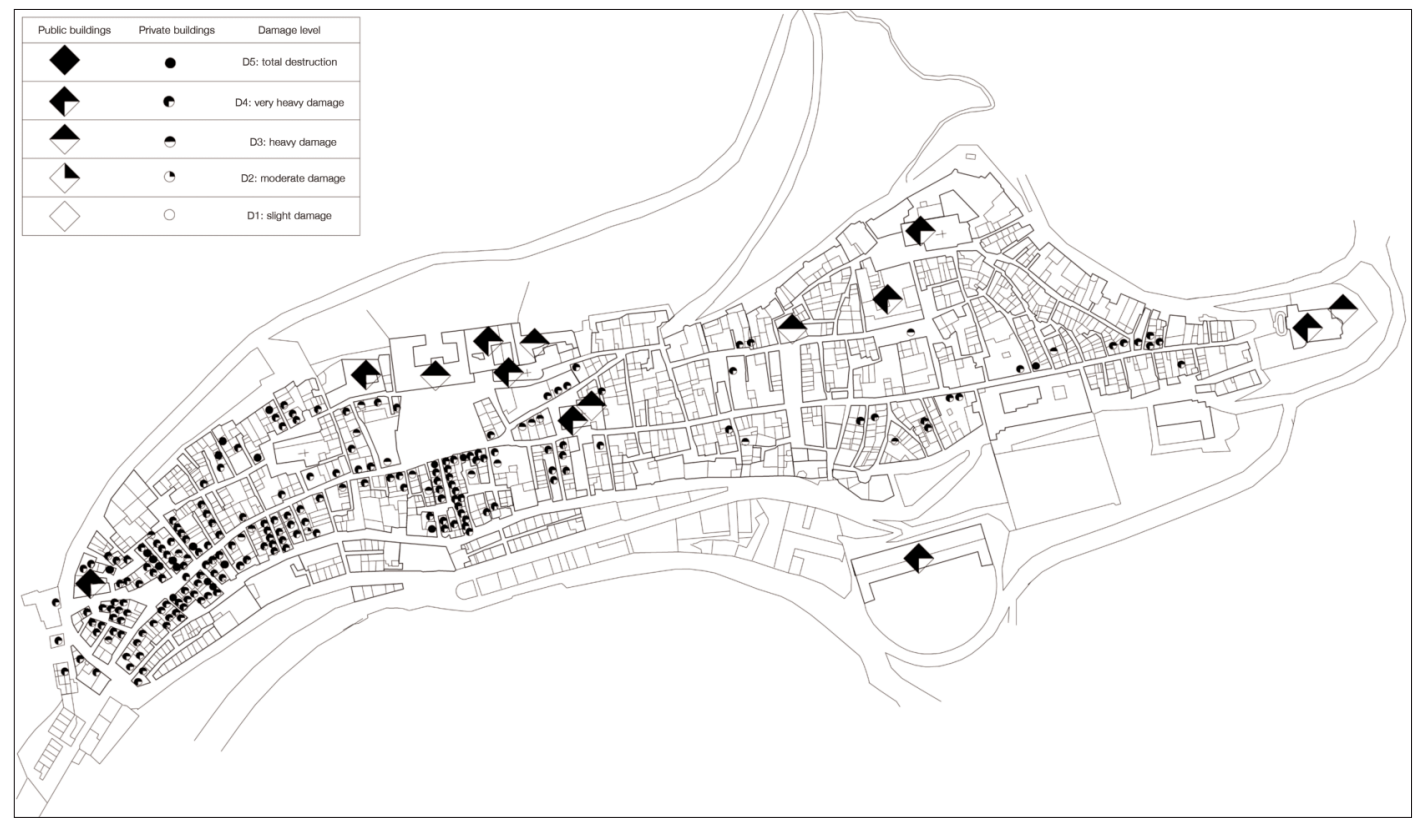

Fig. 7. 1857 damage 'scenario' for Potenza. It is evident that the effects are mainly localised in the western and central-western sector of the historical centre, the so-called Portasalza and Portamendola quarters, where many buildings collapsed (see also fig. 8). 
centre, the so-called Portasalza and Portamendola quarters, where many buildings collapsed. The eastern flank of the hill on which the town lies was also heavily hit.

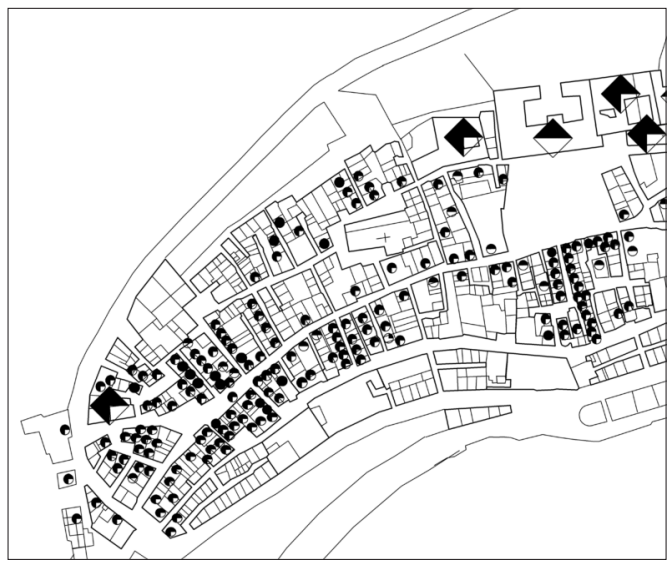

Fig. 8. 1857 'scenario' for Potenza: detail of damage in Portasalza-Portamendola quarters, where many buildings collapsed.
For the 1930 earthquake, the damage pattern was also 'reconstructed' using original sources that have never been referenced elsewhere. We refer to the written sources from the Potenza $\mathrm{Mu}-$ nicipal Archive and the Potenza Monuments and Fine Arts Office Archive (see Appendix).

The Municipal Archive sources include correspondence between the owners and the prefecture. We also examined two lists of damaged buildings prepared by the Office of Civil Engineers (Genio Civile) and the town council. These data are the only available documentation, because Potenza was not included among localities where a public subsidy was granted for rebuilding. Because there was greater damage to other towns (e.g., Gizzi and Masini, 2004, 2006), detailed damage to Potenza was not documented by the Office of Civil Engineers.

The available information refers to damage to about 90 buildings, including public and religious buildings. These data almost agree with Alfano (1931), who reported damage to 80 buildings. This scientist probably only considered dwellings in his computation.

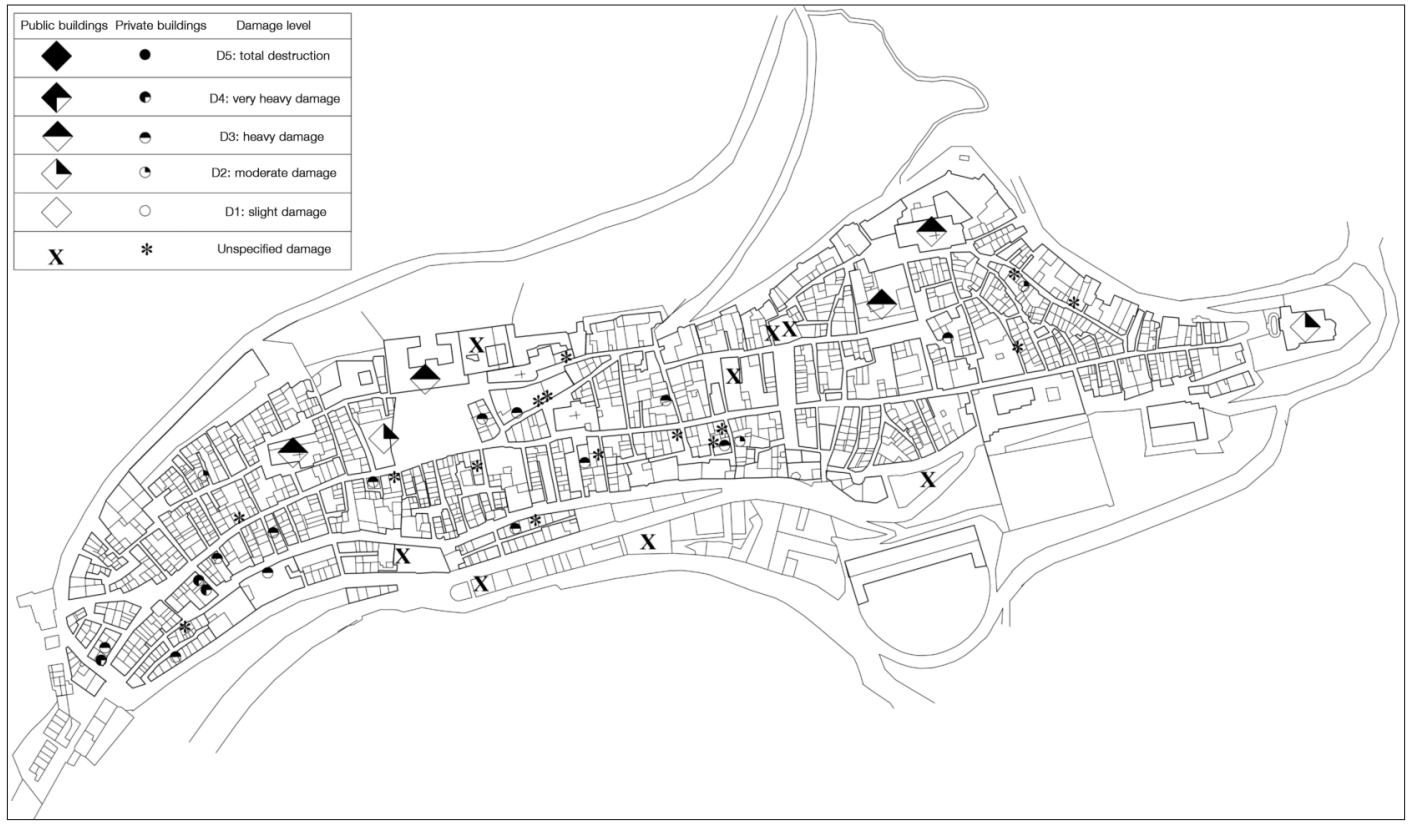

Fig. 9. 1930 damage 'scenario' for Potenza. It can be noticed that the damage is especially located in the central-western and western portion of the historical centre. 
The Monuments and Fine Arts Office Archive was useful in gathering information about damage to two churches.

Due to the documents consulted, accurate damage classification was not possible in many cases. However, completing the damage map represents a significant increase in knowledge about seismic impact at this location. Indeed, the 'scenario' map clearly shows that damage was mainly localized in the central-western and western parts of the historical centre (fig. 9).

\section{Conclusions}

This paper sheds light on the effects produced to the town of Potenza (Basilicata Region, Southern Italy) by three historical earthquakes: those of 1826, 1857 and 1930. This was mainly achieved by analyzing original written documents, often never consulted before. This study produced three urban maps showing the houses and other buildings that sustained damage. An analysis of the three damage patterns shows that the western flank of the hill and the central-western part of the historical centre suffered the most severe damage.

Even though it is still not possible to define the causes of these differential effects, the data would suggest an influence of building vulnerability, especially for the 1826 seismic event.

However, further research, based on data collection and analysis (e.g., field surveys, boreholes and geophysical prospecting) would clarify the roles of geological, geomorphological, geotechnical and hydrogeological features of the site as regards damage patterns. This would produce important implications for the seismic microzonation of Potenza, based on damage already experienced.

\section{Acknowledgements}

The authors are grateful to an anonymous reviewer and Prof. Antonio Rovelli for their critical reviews and helpful suggestions.

\section{Appendix}

Unpublished primary sources

\section{6 earthquake}

\section{Damage to public buildings}

ASNa (Archivio di Stato di Napoli). Relazione del sottoingegnere Luigi Ciofi al Direttore Generale di Ponti e Strade di Napoli in merito ai danni del terremoto del 1826 a Potenza e Tito. Potenza, 7 Febbraio 1826. Amministrazione Generale di Ponti e Strade, fascio 575, fascicolo 5612.

ASNa (Archivio di Stato di Napoli). Relazione dell'Ingegnere provinciale Marino Massari al Signor Direttore Generale di Ponti e Strade in merito alla visita ai locali dell'Intendenza e dei Tribunali. Potenza, 14 Febbraio 1826. Amministrazione Generale di Ponti e Strade, fascio 575, fascicolo 5618.

ASNa (Archivio di Stato di Napoli). Lettera dell'Ingegnere provinciale Marino Massari al Signor Direttore Generale di Ponti e Strade in merito ai danni ai Tribunali. Potenza, 14 febbraio 1826. Amministrazione Generale di Ponti e Strade, fascio 575, fascicolo 5618.

ASNa (Archivio di Stato di Napoli). Relazione dell'Ingegnere provinciale Marino Massari al Signor Intendente sulle visite ai comuni di Potenza e Tito. Potenza, 05 marzo 1826. Amministrazione generale di Ponti e Strade, busta 575, fascicolo 5613.

ASNa (Archivio di Stato di Napoli). Delibera del Consiglio d'Ingegneri di Acque e Strade in merito alla approvazione del progetto rettificato per lavori all'Ospedale e Torre di S. Carlo. Napoli, 27 Ottobre 1826. Amministrazione Generale di Ponti e Strade, fascio 575, fascicolo 5605.

ASPz (Archivio di Stato di Potenza). Lettera dell'Intendente a Sua Eccellenza Ministro Segretario di Stato Affari Interni in merito ai danni al Monistero di Santa Maria del Sepolcro, 11 novembre 1826. Fondo Intendenza di Basilicata, busta 1359, fascicolo 1. 


\section{Damage to private buildings}

ASPz (Archivio di Stato di Potenza). Lettere varie all'Intendente di proprietari di abitazioni danneggiate dal terremoto. Fondo Intendenza di Basilicata, busta 1359, fascicolo 1.

ASPz (Archivio di Stato di Potenza). Perizia trasmessa dal Sindaco di Potenza all'Intendente su danni ad alcuni edifici di Potenza danneggiati dal terremoto dell' 1 febbraio 1826, Potenza 7 marzo 1826. Fondo Intendenza di Basilicata, busta 1359, fascicolo 1.

ASPz (Archivio di Stato di Potenza). Deliberazione della Deputazione del comune di Potenza incaricata per la visita della case danneggiate dal tremuoto. Notamento delle giornate dei maestri impiegati per la visita delle case di questo comune Capoluogo, nonché delle puntelli impiegati all'oggetto, e di alcune poche fabbriche che si sono eseguite. Potenza, 10 marzo 1826. Fondo Intendenza di Basilicata, busta 1359, fascicolo 1.

$\mathrm{ASPz}$ (Archivio di Stato di Potenza). Lettera di Michele Saracino all'Intendente per ottenere aiuti dopo il diroccamento della sua casa. Potenza, 11 Marzo 1826. Fondo Intendenza di Basilicata, busta 1359, fascicolo 1.

ASPz (Archivio di Stato di Potenza). Deliberazione della Deputazione approvata delle case danneggiate in merito ai provvedimenti da prendersi per la casa di Saverio Assisi. Potenza, 6 aprile 1826. Fondo Intendenza di Basilicata, busta 1359, fascicolo 1 .

\section{7 earthquake}

\section{General information}

ASPz (Archivio di Stato di Potenza), Ordinanza del Consigliere di Corte Suprema di Giustizia in Commissione d'Intendente di Basilicata. Potenza, 17 Dicembre 1857. Fondo Intendenza, busta 1365, fascicolo 62.

ASPz (Archivio di Stato di Potenza), Ordinanza del Consigliere di Corte Suprema di Giustizia in Commissione d'Intendente della provincia di Basilicata. Potenza, 13 Gennaio 1858. Fondo Intendenza, busta 1365, fascicolo 62.

ASPz (Archivio di Stato di Potenza), Deliberazione della Commissione Centrale sull'uso dei Fondi della Colletta. Potenza, 13 giugno 1858. Fondo Intendenza, busta 1363, sottofascicolo 20.

\section{Damage to private buildings}

ASPz (Archivio di Stato di Potenza). Provincia di Basilicata. Stato di coloro che possono meritare i soccorsi della Colletta pei danneggiati dal tremuoto. Comune di Potenza, s.d. Fondo Intendenza, busta 1376, fascicolo 142, Danni nei comuni. Potenza. Sott. 15.

ASPz (Archivio di Stato di Potenza). Provincia di Basilicata. Stato supplettivo di coloro che possono meritare i soccorsi della Colletta pei danneggiati dal tremuoto. Comune di Potenza, s.d. Fondo Intendenza, busta 1376, fascicolo 142, Danni nei comuni. Potenza. Sott. 15.

ASPz (Archivio di Stato di Potenza). Lettere varie dei proprietari all'Intendente per ottenere Fondi dalla Colletta generale. Fondo Intendenza, busta 1361, fascicolo 7.

$\mathrm{ASPz}$ (Archivio di Stato di Potenza). Lettere varie dei proprietari all'Intendente per ottenere Fondi dalla Colletta generale. Fondo Intendenza, busta 1365, fascicolo 34.

ASPz (Archivio di Stato di Potenza). Lettere varie dei proprietari all'Intendente per ottenere Fondi dalla Colletta generale. Fondo Intendenza, busta 1376, fascicolo 142, sottofascicolo 2.

ASPz (Archivio di Stato di Potenza). Lettere varie dei proprietari all'Intendente. Fondo Intendenza, busta 1376, fascicolo 142, sottofascicolo 1.

ASPz (Archivio di Stato di Potenza). Lettere varie dei proprietari all'Intendente per ottenere Fondi dalla Colletta generale. Fondo Intendenza, busta 1376, fascicolo 142, sottofascicolo 14.

ASPz (Archivio di Stato di Potenza). Notamento delle ordinanze emesse dal Direttore delle Opere Pubbliche nella Provincia, per demolizione, e puntellature di casamenti in Potenza. Potenza 23 gennaio 1858. Fondo Intendenza, busta 1376, fascicolo 142, sottofascicolo 1 .

ASPz (Archivio di Stato di Potenza). Deliberazione della Commissione locale per gli affari del terremoto. Potenza, 19 ottobre 1858. Fondo Intendenza, busta 1361, fascicolo 7.

ASPz (Archivio di Stato di Potenza). Lettera del Sindaco Iannelli al Signor Intendente in merito allo stato supplettivo dei danneggiati dal terremoto. Potenza, 20 ottobre 1858, Fondo Intendenza, busta 1361, fascicolo 7, Stato dei danneggiati nei Comuni dei Distretti di Potenza, Matera, Melfi e Lagonegro.

ASPz (Archivio di Stato di Potenza). Lettera del Sindaco di Potenza all'Intendente relativa alla ricostruzione della casa di Gerardo Albano. Potenza, 31 Maggio 1859, busta 1376, fascicolo 142, sottofascicolo 15. 


\section{Damage to public buildings}

ASPz (Archivio di Stato di Potenza). Lettera del Comando delle Armi della Provincia di Basilicata all'Intendente in merito alla baracca ove trovasi alloggiata la Compagnia di Difesa. Potenza, 14 agosto 1858. Fondo Intendenza, busta 1376, fascicolo 142 .

ASPz (Archivio di Stato di Potenza). Lettera della 2a Divisione della Fanteria-Comando della 5a Compagniaall'Intendente in merito alle baracche che hanno lasciato. Potenza, 10 ottobre 1858. Fondo Intendenza, busta 1376 , fascicolo 142.

ASPz (Archivio di Stato di Potenza). Lettera del Sindaco di Potenza all'Intendente per la costruzione di una baracca per stabilirvi provvisoriamente l'Ufficio della Cancelleria comunale. Potenza, 20 dicembre 1857. Fondo Intendenza, busta 1376, fascicolo 142.

ASPz (Archivio di Stato di Potenza). Lettera del Ministero e Real Segreteria di Stato all'Intendente in merito ai danni dei Tribunali. Potenza, 21 dicembre 1857. Fondo Intendenza, busta 1376, fascicolo 142, sottofascicolo 16.

ASPz (Archivio di Stato di Potenza). Lettera del Corpo degl'Ingegneri delle Acque e Strade della Provincia di Basilicata all'Intendente in merito ai gravi danni al Tribunale Civile, Gran Corte Criminale, Direzione dei dazi diretti ed indiretti, Regio Giudicato. Potenza, 25 dicembre 1857. Fondo Intendenza, busta 1376, fascicolo 142, sottofascicolo 16.

ASPz (Archivio di Stato di Potenza). Lettera del Ministero e Real Segreteria di Stato all'Intendente in merito ai danni dei Tribunali. Potenza, 21 dicembre 1857. Fondo Intendenza, busta 1376, fascicolo 142, sottofascicolo 16.

ASPz (Archivio di Stato di Potenza). Lettera del Direttore dei Lavori Pubblici della Provincia di Basilicata all'Intendente in merito alla verifica dei lavori occorrenti nella caserma della Gendarmeria Reale di Potenza. Potenza, s.d. Fondo Intendenza, busta 1376, fascicolo 142, sottofascicolo 1.

ASPz (Archivio di Stato di Potenza). Lettera del Comando di Guardia Urbana di Potenza all'Intendente in merito alla baracca provvisoriamente destinata a Corpo di Guardia. Potenza, 1 giugno 1858. Fondo Intendenza, busta 1376, fascicolo 142, sottofascicolo 14.

ASPz (Archivio di Stato di Potenza). Progetto estimativo sommario di taluni lavori urgenti che bisognano per rimettere nel pristine varie case di proprietà del Comune di Potenza, danneggiate dal terremoto del 1857. Esercizio del 1858. Potenza, 6 luglio 1858. Fondo Intendenza, busta 1058.

ASPz (Archivio di Stato di Potenza). Lettera del Comando delle Armi nella Provincia di Basilicata al Signor Intendente in merito alle famiglie dei soldati della Compagnia di Difesa. Potenza, 3 gennaio 1858. Fondo Intendenza, busta 1363, fascicolo 20 .

ASPz (Archivio di Stato di Potenza). Lettera del Comando della Gendarmeria Reale in Basilicata-2a Divisionein merito ai danni al muro della scuderia della Gendarmeria prodotti dalle altre scosse di terremoto. Potenza, 19 dicembre 1857. Fondo Intendenza, busta 1363, fascicolo 16.

ASPz (Archivio di Stato di Potenza). Lettera del Corpo degl'Ingegneri delle Acque e Strade della Provincia di Basilicata sui danni cagionati dal tremuoto agli edifici pubblici di Potenza. Potenza, 21 gennaio 1858. Fondo Intendenza, busta 1365 , fascicolo 50 .

ASCPz (Archivio di Stato di Potenza). Lettera dell'Intendente al Sindaco di Potenza per la redazione di perizie occorrenti alla casa comunale di questo capoluogo e di altri edifizi di proprietà del comune. Potenza, 17 marzo 1858 , busta 1339 , fascicolo 3 .

ASCPz (Archivio di Stato di Potenza). Progetto e stato estimativo sommario di taluni lavori urgenti che bisognano per rimettere nel pristino stato varie case di proprietà del comune di Potenza danneggiate dal terremoto. Potenza, 6 luglio 1858. Provincia di Basilicata, busta 1339, fascicolo 3.

ASPz (Archivio di Stato di Potenza). Lettera del Ministero e Real Segreteria di Stato all'Intendente in merito agli interventi sulla Chiesa Costantiniana di S. Antonio Abate in Potenza, rovinata dal tremuoto. Potenza, 10 ottobre 1858. Fondo Intendenza, busta 1376, fascicolo 142, sottofascicolo 22.

ASPz (Archivio di Stato di Potenza). Lettera del Regio Cappellano all'Intendente in merito ai danni alla Chiesa Costantiniana di S. Antonio Abate in Potenza. Potenza, 2 febbraio 1858. Fondo Intendenza, busta 1376, fascicolo 142, sottofascicolo22.

ASPz (Archivio di Stato di Potenza). Lettera Del Funzionario del Commissariato di Polizia all'Intendente in merito alle abitazioni che è necessario demolirsi. Potenza, 11 s.m. 1858. Fondo Intendenza. busta 1376. fascicolo 142, sottofascicolo 1 .

ASPz (Archivio di Stato di Potenza). Lettera del Comandante delle Armi della provincia di Basilicata all'Intendente in merito all'alloggiamento della Compagnia di Difesa. Potenza, 14 agosto 1858. Fondo Intendenza, busta 1376, fascicolo 142 .

ASPz (Archivio di Stato di Potenza). Lettera della 2a Divisione della Fanteria-Comando della 5a Compagnia al- 
l'Intendente in merito all'alloggiamento degli individui della Compagnia. Potenza, 19 ottobre 1858. Fondo Intendenza, busta 1376, fascicolo 142 .

ASPz (Archivio di Stato di Potenza). Lettera del Sindaco di Potenza all'Intendente per la costruzione di una baracca da adibire a Cancelleria comunale. Potenza, 20 dicembre 1857. Fondo Intendenza, busta 1376. fascicolo 142.

ASPz (Archivio di Stato di Potenza). Lettera del Capo Urbano al Comando della Guardia Urbana di Potenza relativa a due case crollanti site in Vico Corrado. Potenza, 18 dicembre 1857. Fondo Intendenza, busta 1376, fascicolo 142, sottofascicolo 1.

ASPz (Archivio di Stato di Potenza). Lettera dalla baracca dei Padri Gesuiti all'Intendente relativa alla necessità di formarsi un sito per gli atti pubblici di religione. Potenza, 18 dicembre 1857. Fondo Intendenza, busta 1376, fascicolo 142, sottofascicolo 1 .

ASPz (Archivio di Stato di Potenza). Lettera dell'Intendente al Vescovo di Marsico e Potenza in merito alla riattazione della Cappella di Santa Lucia. Potenza, 22 luglio 1858. Fondo Intendenza, busta 1360, fascicolo 6, sottofascicolo 35 .

ASPz (Archivio di Stato di Potenza). Lettera del Vescovo di Marsico e Potenza all'Intendente in merito alla trasmissione della perizia eseguita per le spese di riattazione della Cappella di Santa Lucia. Potenza, 29 luglio 1858. Fondo Intendenza, busta 1360, fascicolo 6, sottofascicolo 35.

ASPz (Archivio di Stato di Potenza). Lettera del Vescovo della Diocesi di Marsico e Potenza all'Intendente relativa alla costruzione della Chiesa provvisoria della SS. Trinità nel Largo dell'Intendenza. Potenza, 23 gennaio 1858. busta 1376, fascicolo 142, sottofascicolo 1 .

\section{0 earthquake}

\section{Damage to private buildings}

ASCPz (Archivio storico comunale di Potenza). Trasmissione da parte del Municipio di Potenza al Provveditorato alle Opere Pubbliche dell'elenco dei fabbricati danneggiati dal terremoto del 23 luglio 1930-denunziati all'Ufficio Tecnico Comunale. Potenza 6 ottobre 1930, busta 1441, fascicolo 1.

$\mathrm{ASCPz}$ (Archivio storico comunale di Potenza). Ordinanza del Podestà di Potenza relativa allo sgombero di un appartamento in Piazza Trinità ed all'esecuzione di lavori di restauro. Potenza, 30 Luglio 1930. busta 1441, fascicolo 1.

$\mathrm{ASCPz}$ (Archivio storico comunale di Potenza). Lettera del Podestà al proprietario Albanese Domenico in merito ai danni e lavori occorrenti all'appartamento. Potenza, 30 luglio 1930, busta 1441, fascicolo 1.

ASCPz (Archivio storico comunale di Potenza). Corpo Reale del Genio Civile. Ufficio di Potenza. Elenco Nominativo delle domande pervenute e da rinnovare secondo il modello che si acclude. Potenza, 14 Aprile 1931. busta 1441, fascicolo 1.

ASCPz (Archivio storico comunale di Potenza). Lettere varie di proprietari di abitazioni danneggiate circa la richiesta di verifica dei danni, busta 1441, fascicolo 1.

\section{Damage to public buildings}

ASCPz (Archivio storico comunale di Potenza). Amministrazione Provinciale di Potenza. Denuncia fatta dall'Ingegnere Capo in merito ai danni al Palazzo del Governo, Convitto Nazionale ed Ospedale Civile S. Carlo. Potenza, 14 agosto 1930, busta 1441, fascicolo 1 .

ASCPz (Archivio storico comunale di Potenza). Lettera del Commissario Prefettizio al Preside del Liceo Ginnasio «Luigi La Vista» in merito allo stato delle aule. Potenza, 5 settembre 1930, busta 1441, fascicolo 1.

ASCPz (Archivio storico comunale di Potenza). Lettera del Consiglio Provinciale dell'Economia di Potenza al Commissario Prefettizio circa la richiesta di un sopralluogo tecnico. Potenza, 16 Agosto 1930, busta 1441, fascicolo 1.

ASCPz (Archivio storico comunale di Potenza). Lettera dell'Istituto Autonomo Case popolari al Commissario Prefettizio circa la richiesta di un sopralluogo tecnico. Potenza, 17 Agosto 1930, busta 1441, fascicolo 1.

ASCPz (Archivio storico comunale di Potenza). Lettera dell'Arcidiacono del Capitolo di San Gerardo in Potenza al Commissario Prefettizio per la richiesta di un sopralluogo tecnico. Potenza, 18 Agosto 1930, busta 1441, fascicolo 1.

ASCPz (Archivio storico comunale di Potenza). Lettera del Circolo Lucano del Littorio al Commissario Prefettizio di Potenza. Potenza, 18 Agosto 1930, busta 1441, fascicolo 1.

ASCPz (Archivio storico comunale di Potenza). Lettera Priore Domenico Manzo circa la richiesta di un sopralluogo tecnico alla Chiesa di S. Maria. Potenza, 23 Agosto 1930, busta 1441, fascicolo 1. 
ASCPz (Archivio storico comunale di Potenza). Trasmissione da parte del Municipio di Potenza alla Prefettura dell'elenco degli edifici pubblici danneggiati dal terremoto. Potenza, 11 Agosto 1930, busta 1441, fascicolo 3.

ASBAAPz (Archivio soprintendenza per i beni ambientali ed architettonici di Potenza). Chiesa cattedrale, busta MPZ/62/I.

ASBAAPz (Archivio soprintendenza per i beni ambientali ed architettonici di Potenza). Chiesa di San Michele, busta MPZ/62/B.

\section{Other archive sources}

ASCPz, Elenco complateari di Via Pretoria. Relazione dell'Ingegnere Vincenzo Pascale per la realizzazione del condotto sotterraneo in Via Pretoria. Con schizzo planimetrico. 8 Febbraio 1857, busta 1304.

ASCPz, Elenco delle case demolite per costruire il nuovo Teatro. 17/01/1858. Fondo Intendenza B. 1054bis fascicolo 1170d.

\section{Daily newspapers}

Gazzetta del Mezzogiorno 30/12/1980.

Il Mattino, 08/12/1980.

Il Nuovo Corso 10/02/1981.

\section{REFERENCES}

Alfano, G.B. (1931): Il terremoto Irpino del 23 luglio 1930. Pubblicazione dell'Osservatorio di Pompei.

Angelini, G. (1995): Il Consiglio edilizio di Potenza (18441861). Inventario e catalogo dei disegni, Potenza.

Boschi, E., A. Morelli, A. Piersanti and A. Rovelli (1999): Seismology and physics of the Earth's interior, Boll. Geofis. Teor. Appl., 40 (2), 93-157.

Boschi, E., E. Guidoboni, G. Ferrari, D. Mariotti, G. VALENSISE and P. GASPERINI (2000): Catalogue of Strong Italian Earthquakes from 461 B.C. to 1997, Introductory texts and CD-ROM (Version 3 of the Catalogo dei Forti Terremoti in Italia), Ann. Geofis., 43 (4). pp. 268 with CD-ROM.

BuCCARO, A. (Editor) (1997): Le Città nella Storia d'Italia: Potenza, Bari.

Demanet, D., L. Margheriti, G. Selvaggi and D. JongMANS (1998): Upper crustal structure in the Potenza area (Southern Apennines, Italy) using Sp converted waves, Ann. Geofis., 41 (1), 105-119.

GizzI, F.T. (2006): To what degree can historical seismicity records assist in seismic microzonation?, Eng. Geol., 87, 1-12.

GizZI, F.T. and N. MASINI (2004): Damage scenario of the earthquake on 23 July 1930 in Melfi: the contribution of technical documentation, Ann. Geophysics, 47 (5), 1641-1664.

GizZI, F.T. and N. MASINI (2006): Historical damage pattern and differential seismic effects in a town with ground cavities: a case study from Southern Italy, Eng. Geol., 88, 41-58.

GRÜNTHAL, G. (Editor) (1998): European Macroseismic Scale 1998, Cahiers du Centre Européen de Géodynamique et de Séismologie, Luxembourg.

Guidoboni, E., D. Mariotti, M.S. Giammarino and A.
RovelLI (2003): Identification of amplified damage zones in Palermo, Sicily (Italy), during the earthquakes of the last three centuries, Bull. Seismol. Soc. Am., 93 (4), 1649-1669.

ISTAT (2005): Bilancio Demografico Anno 2004 e Popolazione Residente al 31 Dicembre (available on line: http://www.demo.istat.it/bil2004/index02.html).

LOMBARDI, A. (1829): Cenno sul tremuoto avvenuto in Tito, ed in altri luoghi della Basilicata il dì primo Febbraio 1826, Potenza.

Mallet, R. (1862): The Great Neapolitan Earthquake of 1857, London, 2 voll. (reprinted by Istituto Nazionale di Geofisica, Roma, 1987).

Pacichelli, G.B. (1695): Tremuoto di Napoli, e del Regno à puntino spiegato (Al Signor Abate Francesco Battistini Maestro di Camera dell'Eminentiss. Negrone, Roma), in D.A.Parrino, Lettere Familiari, Istoriche, \& Erudite, tratte dalle Memorie Recondite dell'Abate D. Gio. Battista Pacichelli in occasione de' suoi Studj, Viaggi, e Ministeri, vol. 2, 353-363.

Rossi, P.E. (1868): La Basilicata: libri tre. Studi politici, amministrativi e di economia pubblica, Verona.

SAnNino, A.L. (1990): Territorio e Popolazione a Potenza nell'Età Moderna, Roma.

Tertulliani, A., M. Anzidei, A. Maramai, M. Murru and F. RiguZZI (1992): Macroseismic study of the Potenza (Southern Italy) earthquake of 5 May 1990, Nat. Hazards, 6 (1) 25-38.

TOMACELli, C. (1892): Memorie storiche intorno la vita dell'eminentissimo e reverendissimo principe Sisto $R i$ ario Sforza, cardinale prete della S.R.C., del titolo di Santa Sabina arcivescovo, Napoli.

(received July 10, 2007; accepted November 12, 2007) 